\author{
Daiva Račiūnaitė-Vyčinienė \\ https://orcid.org/0000-0002-3859-9923 \\ Department of Ethnomusicology at Lithuanian Academy of Music and Theatre \\ Vilniaus str. 6-2, LT-01110 Vilnius, Lithuania \\ тел.+370 524974 87, e-mail: daiva.vyciniene@lmta.lt
}

\title{
Today's Singing Tradition of Lithuanian Polyphonic Songs Sutartinės: Relations of Western and Eastern Cultures
}

\begin{abstract}
The dichotomy "East-West" is a philosophical concept of ancient origin. Despite the fact that East and West can be interpret and understood as a cultural hemisphere, it is necessary to talk about their commonalities and points of contact. In an article author notes, drawing on her many years of singing practice and scientific research, that the music of sutartines is understood not as a mix of different vocal parties, but as a sounding pulsating space. In this sense, sutartinés are close to minimalistic - music and visual art-works which are characterised by the multiple repetition of elements, their severity and precision. In performing sutartines, just like Eastern traditional music, one characteristic is to, through controlled emotion, "enter" one certain state and remain in it for a long time. Speaking about sutartines, the author discusses old Lithuanian relations with the East, which are not so much a geographical, but more mental. It is known that the West in general is characterized by the propensity to search for manifestations of spirituality in the East. Therefore, the links of sutartines with the East may be the result of this search. The author raises the question of whether the modern tendency of young people to sing the sutartines may be the result of the search for spirituality in Eastern culture, or the spirit of the East rather than the West lies in the very nature of sutartinès. Modern music projects, bringing together Western and Eastern cultures, helps to understand the original features of the sutartinés and possibilities of "western" meditation.
\end{abstract}

Keywords: sutartinès, Lithuanian minimalism, spirituality, Orient in Lithuania, the West-East, dialogue of cultures

The subject of my papers - Lithuanian multipart songs sutartines inscribed in 2010 on the Representative List of the Intangible Cultural Heritage of Humanity. Features most characteristic of vocal and instrumental polyphony, second accords, complementary rhythms and syncopation, indicate a powerful, unique musical system of thought per sutartinés ${ }^{*}$ (Ex. 1. Du Dobilèli Trys Ratileli.wawe).

Sutartines were part of the old belief system and its rituals, and undoubtedly represent the sacred part of the sacrum/profanum duality. According to the old sources, sutartines were sung by none other than sprites and witches. This lets us surmise that the singers of sutartines were important participants or organizers of rituals. The sacredness of sutartines as well as the extraordinary status of the singers is revealed by several factors. Nineteenth century linguist Mykolas Miežinis wrote down the testimony of one singer who claimed that "their mothers knew such songs, which they kept secret and sang very rarely; the words were held in high esteem, and were considered unalterable" ${ }^{\prime *}$. Keeping them in secret, and the honor bestowed on those unalterable words indicated their special significance and the sacredness of the sutartines. This peculiar fear is also mentioned by researcher Mykolas Biržiška who wrote down these comments: "For people of our times sutartines sometimes appear mysterious and it is said that they come to us through sprites and fairies, (initially the Goddess of Birth and Earth in Eastern Baltic mythology) Afterwards, when people had become Christians, they only referred to them as witches" (Biržiška, 1921, 31).

We have several documented tales about sprites who were the singers of sutartines. In one of them (written down in 1968 from informant Ksaveras Ilgevičius at the age of 75) three sprites who lived several kilometers one from the other would sing a sutartine (Dovydaitis, 1987, 474). The fact that laumés or sprites sing the sutartines is important evidence of just how exceptional these songs were.

DOI: https://doi.org/10.31318/2522-4212.2019.14.183852

${ }_{1 *}^{*}$ Sutartines, Lithuanian multipart songs http://www.unesco.org/culture/ich/en/RL/sutartines-lithuanian-multipart-songs-00433

1* Русское географическое общество (Archives of the Russian Geography Association in St. Petersburg), 1, nr. 31, p. 89. 
Accoring to folklorist Norbertas Vèliaus, the word ragana or witch is quite old, related to the words for oracle or sorcerer. The word ragana has its origins in the word regeti - to see. She can see into the future, she is clairvoyant; the expert on things unseen (Vèlius, 1977, 128). Of course, we might question whether tales and testimonies can be firm proof of the social and religious status of sutartine singers of the past. In this case we might rely on the opinion of semioticist Algirdas Julius Greimas, who has said that, "even the seemingly most stupid idea or tale has its grounds and can be explained. The object of mythology is not the world and its things, but that which a person thinks about the world, about things, and about himself" (Greimas, 1990: 29). On the one hand we might surmise that those specializing in the singing of sutartines were witches, sorcerecces or oracles according to the conception of that day. On the other hand, these women might have been labeled witches as the sutartine tradition was beginning to wane (as keepers of the old traditional hymns, which were now incomprehensible to others; the experts on mysterious matters). Folklorist Bronè Kerbelyte holds a similar view of witchery. "First there came a change in the conception of magic. It diminished in the everyday lives of most people and more conservative people were made fun of or they were considered dangerous witches and warlocks" (Kerbelyte, 1999: 246). However, as time went on, sutartinés lost their connection to ritual. We can note changes in both the worldview and the aesthetics as regards sutartinès (RačiūnaitèVyčinienè, 2002; 2005; 2010; 2012a, etc).

In the middle of the 20th Century, the natural transmission of sutartines from one generation to the next has ceased for all practical purposes in the rural areas of Lithuania. Before the group performance tradition finally died in the rural areas, the sutartines were widely misunderstood by the beginning of the $20^{\text {th }}$ century; its practitioners were viewed negatively and were mocked. At the beginning of the twentieth century there was a marked change in musical aesthetics - a general tendency towards romanticism, the rapid spread of so-called literary songs and ballads known as "romances," folk song arrangements for chorus, polished vocal performances - the antithesis of the open-throat, chesty manner of singing. All of this altered the common folks' perception of sutartines. The singing of these archaic songs provided less and less aesthetic satisfaction, and the sutartines themselves were mocked. Elzbieta Janavičienè, born in 1841 stated, "When they would make fun of us, saying that that we cackle like hens, then we would sing them in one voice" (in other words - not polyphonically). Another singer of sutartiness, Elzbieta Bratenaite, born in 1852 sang a sutartine parody for Stasys Paliulis, an expert on sutartines. According to the informant, this parody of cackling hens was sung by young men who would make fun of the female singers (Paliulis, 1959, 413):

Čia tavo
Čia mano

Sudesim abieju, Bus tik mūsų dviejų. ${ }^{1}$

It would be difficult to trace the origins of the sutartine "Vištela karkè" (S1S 621), which contains a refrain imitating the "language" of hens: kudi kudi, $k u d i-k a-k a$ (instead of traditional vocables such as tatato, lingo rita, which are found in other versions of this sutartine):

Vištela karkè,

Žirnelius tarpe.

Kudi, kudi, kudi kaka,

Kudi, kudi, kudi kaka...

The hen crackled, taking care of the peas,

Kudi, kudi, kudi kaka,

Kudi, kudi, kudi kaka...

Is this the work of those who were not fans of sutartines? A parody of the singing style? Or was this a case of autoirony in which the singers themselves made fun of the strange cackling that their singing emitted? ${ }^{2}$

We see a similar transformation of a traditional vocable into a hen imitation in another case, further demonstrating the derisive attitude towards the singing of sutartines. Singer M. Juknys (from the region of Utena) recalled how the "old women would cackle as they harvested rye. One old woman or girl would repeat only one phrase: Who sowed the rue? The other would answer: Sister sowed the rue. The third one would say: Ku de ka ka ka!" (2 times.) <...>. Sometime a fourth one would join in but with no words, just a drone: $\bar{U}-\bar{u}-\bar{u}-\bar{u}-\bar{u} . .$. That kind of singing would make us laugh a lot. Then we would say "The old women have started to cackle like hens" (LTR 1948(195)). Therefore, in the beginning of the twentieth century the comparison of sutartines to the cackling of hens is no longer a melodic or articulation characteristic, but a reflection of the attitudes of listeners, who considered this type of singing to be unattractive, incomprehensible, a chaotic clamour.

\footnotetext{
${ }^{1}$ Translation: These are your eggs, these are mine. We'll put them together, and they will be ours.

2 The "cackling like hens" description regarding sutartines may have several meanings: 1) a reflection of key sutartine performance practices: the rapid "hopping" from one pitch to another, the accentuation of selected pitches, the simultaneous sounding of different texts and melodies - the general clamour; 2) an indication of changes in twentieth century music aesthetics, a different view of sutartines among the rural population.
} 
So many folklorists of the first half of the twentieth century spoke of the complete disappearance of sutartines. However, in the 1960 s they were being performed in the larger cities of Lithuania, attaining a different and new meaning (Račiūnaitè-Vyčinienè, 2012b).

Today sutartines are as exotic to young people as the musics of other cultures. They have numerous characteristics that are atypical of the remaining repertoire of Lithuanian folklore - bitonality, bitextualism (when meaningful texts as well as vocables are simultaneously performed), the dominance of the interval of a second, complementary rhythm, syllabic articulation, and a rich vocabulary of vocables ${ }^{3}$ [Fig. 1].
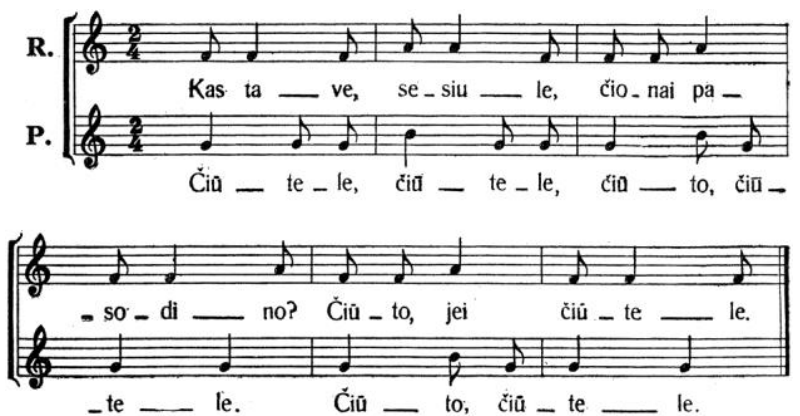

Figure 1. Kas tave, sesiule. Wedding sutartine sung by Ona Smilgienè, age 74, Papilys district, Biržai region

(Slaviūnas 1958 II, 408, nr. 842)

Yet this exotic and barely understood vocal form is the place where they go to find spirituality. How can this be explained? Is this the trend of the day? What draws young people to sutartines? When I perform in other European countries with my group of sutartines singers Trys Keturiose I see that they leave an impression on non-Lithuanians as well. One possible premise is that this corresponds with the general tendency in the West to search for spirituality in the East (Deschênes, 2005; Keister, 2005; Genzelis, 2005; Beinorius, 2011, and others).

As is widely known, the Western world turned towards the East in the $19^{\text {th }}$ and $20^{\text {th }}$ centuries, when Europe became spiritually vulnerable. For several centuries a stereotyped distinction has endured, stating that the West is dominated by the active, rational, material side of the human psyche, while the East represents its passive, contemplative, spiritual side. It is still generally thought that the source of true values may be solely found in the East, which is defined by

\footnotetext{
${ }^{3}$ Sutartines texts contain an abundant number of archaic refrains: linagõ, taduvõ, čiūto rūto, tatatõ, siuli siulingèla, siudijõ, dūno, rititatatõj, minagaučio, dautuvõ, ritingõ, tūto be tūtõ, judabrõ and others; the meanings of these words, these days, are indecipherable. These refrains, devoid of any semantic meaning, generally consist of interjected onomatopoeic sounds that are especially important to the rhythm of the sutartines.
}

its oral culture and belief in the magical power of words.

As maintained by French philosopher René Guénon (1886-1951), some common features have been preserved in the Eastern civilizations, which might be subsumed under the term 'traditional civilization' and which have been lost in the Western civilization. There was no reason for opposition between East and West as long as there were traditional civilizations in the West as well as in the East. This opposition, in the philosopher's opinion, has meaning only as far as the modern West is concerned, for "it is far more an opposition between two mentalities than between two more or less clearly defined geographical entities." The lost tradition, according to Guénon, "can be restored and brought to life again only by contact with the living traditional spirit, and, as we have already said, it is only in the East that this spirit is still fully alive" (Guénon 2002).

However, the real cultural and geopolitical East, as pointed out by literary scholar Regimantas Tamošaitis, displays such great diversity that may not necessarily correspond to the stereotyped vision of the East. The latter appears to be merely a figure of speech, an ideological construct of language. Then the East may be regarded as a transcendental ideal, wealth of spiritual life that lies beyond the bounds of our world (Tamošaitis, 2012, 8-9). Carl Gustav Jung was of similar opinion, claiming that it is not a geographical category but rather a spiritual or psychological idea, a repressed and frustrated part of our consciousness [Jung 1970]. Therefore the Eastern world is not only located in a different realm, but is also essentially different in terms of quality and time, which might be described as archetypal, mythical. Such vision of the Orient was adopted by the romantics, which became successfully revived in the context of $21^{\text {st }}$-century non-traditional cults and cultures.

Speaking of the Lithuanian culture in particular and its ties with the East, one may conclude that these ties are not entirely superficial or influenced by the general tendency to look for spiritual values in the East, which is prevalent in the West. Many Lithuanian culturologists point to the fact that the issues of interaction between Eastern and Western mentalities have never lost their significance in the context of Lithuanian culture. It is generally accepted that the ancestors of Lithuanian nation moved to Europe from Asia and for this particular reason the archetypal forms of Lithuanian traditional culture preserved many bonds with the eastern world (Andrijauskas, 1991, 255). For example, Lithuanian philosopher Stasys Šalkauskis (1886-1941) argued in the beginning of the $20^{\text {th }}$ century that Lithuania cannot restrict its relations to maintaining contacts only with the Western culture, simply because Lithuanian people have 'Eastern blood' in their origins 
(Šalkauskis, 1991, 153-154). Comparative culturology has shown that there are many vestiges of eastern origin in the constituent elements of Lithuanian culture, such as language, folklore, mythology and indigenous religion - in other words, everything that had shaped a distinct type of Lithuanian ethnicity. The large portion of the linguistic substrate of Lithuanians as a nation has the Indo-European foundation, which holds something that we now refer to as the eastern spirit and whose semantic content remains extant mostly in the language that is akin to the Indo-European protolanguage (Neimantas, 2002). It has been argued that Lithuanian and its dialects have an important role in the investigation of the prehistory of Indo-European languages and reconstruction of their protolanguages. Modern Lithuanian presents a peculiar phenomenon for comparative linguistics. It is related to Sanskrit (a classical language of India), Latin and Ancient Greek (Schmalstieg, 1982; Markevičiene, 2002; Baldi and Dini, 2004, and others). According to the Žaneta's Markevičienè's research, Hindi has unbelievably numerous loan words from Sanskrit, therefore, numerous common items among Sanscrit, Lithuanian and Hindi exist presently, e.g., Lith. smakras - Hind., Skr. śmaśru 'chin'; Lith. medus - Hind. madhu - Skr. mádhu 'honey', etc. Another portion of the common lexicon embraces native Hindi words. It includes common items absent in Sanscrit, e.g. Lith, kulšis - Hind. kūlhā 'hip'; Lith. kupra - Hind. kūbar 'hump'; Lith. begti 'to run' - Hind. bhānā 'to run away'; Lith. kukurbezdalis, kukurdvelkis 'puffball' Hind. kukurmuttā 'musshroom', etc. (Markevičienè, 2002, 113).

Musicologist Jūratė Landsbergyte noted that Lithuania, like no other country in the geopolitical space of Europe, is related to the East through very deep ties that lead to the subconscious level of the nation's mentality (Landsbergyte, 2011). It is no coincidence that orientalism has been conceived by many Lithuanian composers as a search for one' own cultural identity a philosophical projection, enabling to understand one's place in the world. In her words, it is "an allembracing sacred space, a prerequisite of transcendence in music." For this particular reason orientalism in Lithuanian music is not so much a matter of stylistic choice, but rather a "general trend that runs through the whole field of new music." The orientalistic trend acquires its most elaborate form in Lithuanian minimalism that takes its source in the individual styles of Bronius Kutavičius, Mindaugas Urbaitis and Giedrius Kuprevičius. It is in their music that orientalism "matures as a structure and programmatically 'wins over', that is, becomes established in the form of Meditation genre" (Landsbergyte, 2011, 536).

Moreover, the orientalistic notions of eternity, cosmos and universality enabled the Lithuanian composers to reach for a universal level. This even gave rise to the new category in Lithuanian music, nonLithuanian ethnicity (a term coined by Inga Jankauskiene and applied in reference to certain works by Kutavičius (Jankauskienè, 2001, 227)), which defined the unfolding of one's spiritual freedom, one's openness to the world. ${ }^{4}$ In Landsbergyte's opinion, it also defined the ultimate goal of new Lithuanian music: "to expand, to obliterate the limits of the system, to make the structures absolute, extending towards infinity of the universe." In her words, "it was the great nostalgia of Lithuania - to join the ranks of world's oldest nations in the cosmic rhythm of creation" (Landsbergyte, 2011, 538).

The above-mentioned examples clearly illustrate that the notion of the East in Lithuania is far from being solely geographical. To quote once more philosopher Šalkauskis, in search for the Eastern world it would be a misleading path to follow purely geographical guidelines: "the most important thing here is the distinctiveness of cultural and spiritual structure" (Šalkauskis, 1991, 153-154).

However, let us return to the sutartinès. It should be borne in mind that in folk vernacular these sutartines are not called songs, but giesme 'hymns', They were also referred to as hymns by the early collectors, in deference to the classification used by the rural singers, but also with the intent of stressing their distinction from more modern, through-composed songs (ištisinès dainos). Early $20^{\text {th }}$ century collectors included Father Adolfas Sabaliauskas, and Finnish folklorist, Professor Aukusti Robert Niemi. As noted by Father Sabaliauskas, "There is a type of Lithuanian songs that are called hymns. These are not, as some may think, spiritual (or religious) hymns, but secular hymns. And as the old singers say, they are not sung, but chanted. And they never confuse the two: they will never call a song a hymn or a hymn a song. That's how marked the difference is" (Sabaliauskas, 1912, 7). The polyphony of sutartines, an archaic cultural auditory phenomenon, is based on a cyclical conception of time [Fig. 2]. Their sounding is endless, like a closed circle or a wheel. ${ }^{6}$

\footnotetext{
${ }^{4}$ Such works by Kutavičius include his String Quartet No. 3 Anno cum tettigonia (A Year with the Grasshopper) (1980), oratorio The Magic Circle of Sanskrit (1990), based on the poetry of Sigitas Geda and imbued with the spirit of orientalism and 'Lithuania as part of the world,' and some other pieces that had a truly seminal and seismic effect in the Lithuanian music of the time.

${ }^{5}$ In the Lithuanian language, the word for hymn (giesme) is used to describe birdsong, the singing of sutartines, and sacred music performed in church; in a sense - paying respect to all three of these expressions.

${ }^{6}$ Trejine $(s)$ 'threesome(s)' is the most popular form of a singing style. Three singers (sometimes three groups) perform the singing in strict canon. Each enters into the song in stages, while another singer proceeds with the second part of the melody. In other words, the second singer enters, while the first is still singing; the third, while the second one is singing and the first again, while
} 
The fact that the people have referred to the sutartines as apskritos 'round ones' is no mere random occurrence. The ringing of the music itself seems to run in an endless circle. This has also probably had influence on the way the performers arrange the unfolding of the song in a circular fashion (Račiūnaitė-Vyčinienè, 2002, 86) [Fig. 3].

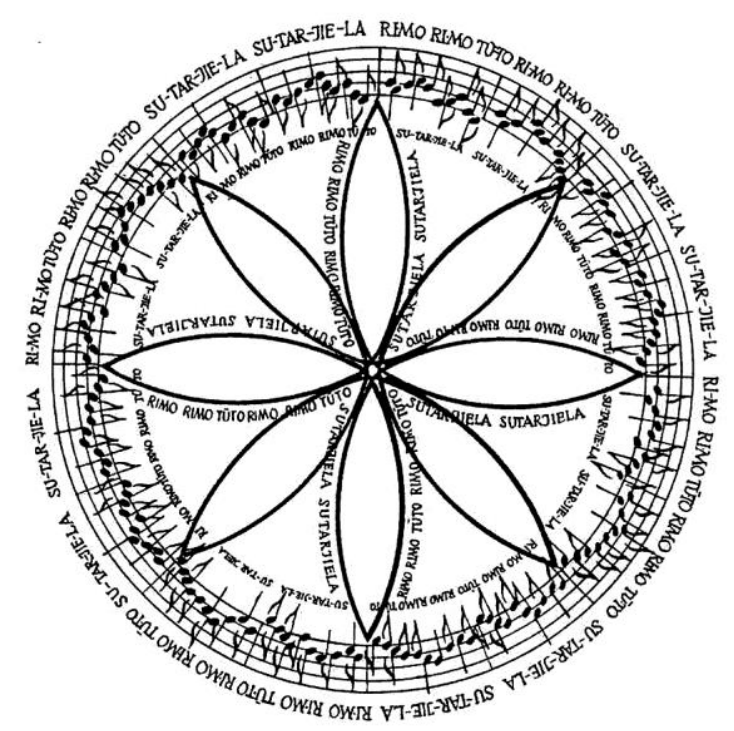

Figure 2. Graphic view of the sutartine "Rimo Rimo Tūto" created by the author, drawn by Algirdas Kuzma

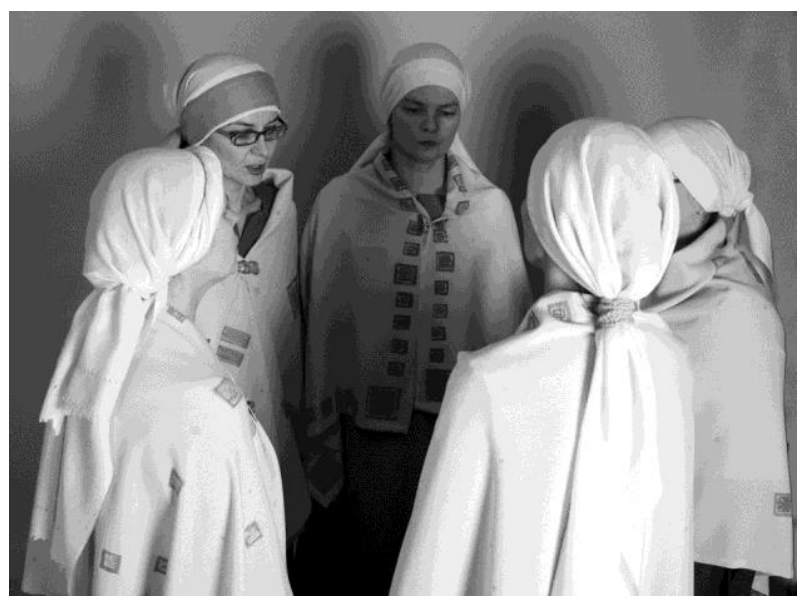

Figure 3. Sutartinès' singers group Trys Keturiose (Jurgita Treinyte, photographer, 2006)

There are no major pauses for breath, no culminations, introductions or final cadences. This allows both the singers and the listeners to immerse themselves into a uniform state of mind and to experience the hypnotic effect. ${ }^{7}$

the third is singing. This way the entire sutartines hymn is sung going around in a circle. Only two voices sound at any one time, except at the first stanza, when the voice of the lead text collector starts the song alone.

${ }^{7}$ The cyclical form of the instrumental sutartines was noted in the second half of the 20th century by Russian musicologist Abram Yusfin (Юсфин, 1968; 1986). Ву making comparisons with similar musical examples from other cultures, he attested to the archaic orginis and the ritual beginnings of sutartines.
Nowadays many singers and listeners perceive sutartines not only as polyphonic singing in groups, which requires a special concord, an "accord", but also as a certain collective meditation. The question is what determines such conception of sutartines. On the one hand, the singers' predilection for a meditative mood can be attributed to the structure of sutartines - a constant recurrence of short musical and textual motifs [Ex. 2. Trys keturiose linelius sejam.avi]. The music of sutartines in general is not seen as the combination of individual voice parts but as a certain pulsatile sounding space of infinite time (Račiūnaitè-Vyčinienè, 2010) [Ex. 3. Saduto tūto.avi]

In this sense, sutartines are very close to minimal music whose first developers (Steve Reich and Philip Glass) were greatly influenced by their acquaintance with the laws of composition of ancient Eastern traditional music as well as with religious-philosophical teachings. Some compo-sers and musicologists (Edwin Geist and others) of the middle of the twentieth century had already observed the relationship of the music of sutartinès with the East.

Sutartines, according to Geist, typically contain short, primitive musical segments that are repeated and have strong common characteristics with the music of Africa (especially Arabic music) and Asian song types. The same kind of rotating structures can be found in the Balkans and in Asia Minor. In the opinion of Geist, this is related to ritual and magic in archaic cultures; the stereotypical repetition of rhythmic and monadic structures provided hypnotic powers (Geist, 1940, 57). The performance of sutartines is similar to that of Asian music in which emotions are restrained and you "enter" into a certain state and remain in it for a prolonged time [Fig. 4]. In Western musical culture the individual artist, the brilliant musician, interpreter or virtuoso is highly esteemed. In Eastern culture there is an emphasis on being in a community. The individual must forget the self and to put forth effort for the good of the collective or the nation. ${ }^{8}$ Much as in sutartines - the individual singer means almost nothing in the here and now. A sutartine is born only when all of the singers are in agreement.

\footnotetext{
${ }^{8}$ It is widely known that in Japan, for example, social rapports are more important than individual autonomy (Deschênes, 2005, 14).
} 


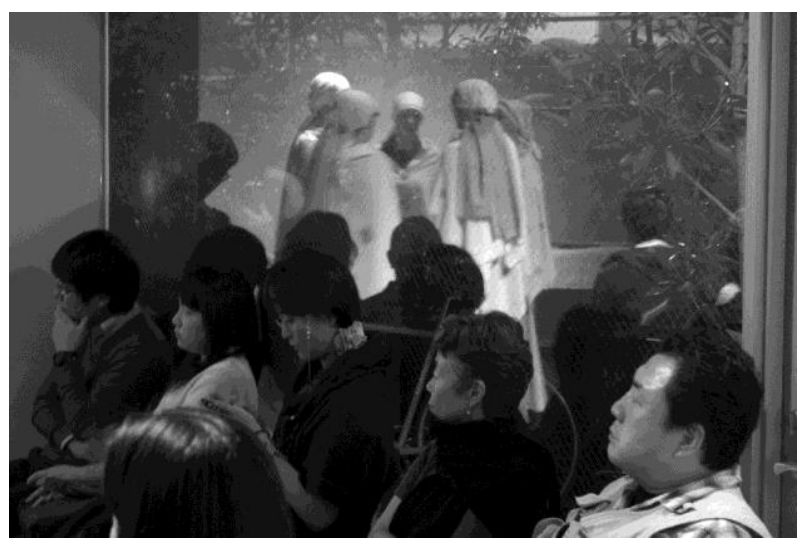

Figure 4. Trys Keturiose during the sutartines, performance in Tokyo, Japan (Gabija Žukauskienè, photographer, 2010)

Eastern traditional pedagogical practices also apply. One of the main principles is oral transmission of the tradition. Of course, some modern Lithuanians find this to be an impossible task - they often ask for written notation and texts. However, my firm belief, based on my own teaching practice, is that this "Eastern" oral teaching method can help today's young people unearth the treasures of sutartines. The teacher in contemporary sutartine singing schools, camps and seminars must become a guru - not merely the formal transmitter of disconnected melodies and texts. He must become a spiritual teacher, one who reveals the inner power of the sutartine spirit. In Eastern traditions (like Japan or India), the teacher attains a godly status in the life of his students $^{9}$. Interestingly, in several sutartine-learning camps I have heard students say, "How lucky we are it's like God himself has arrived!" Of course, this evoked a smile and the glorification seemed unnecessary. However, this may be nothing exceptional if we employ the same type of oral transmission that is encountered in the East. The reception of, the accurate imitation of the sung melody is naturally related to the main principle of the sutartines - canon. As in Eastern culture, the teaching is more intuitive rather than verbalized or theorized.

On the other hand, the present-day conception of sutartines may be influenced by the change in mentality of contemporary Lithuanian people, by the newly acquired knowledge about Eastern spiritual practices and so forth ${ }^{10}$.

\footnotetext{
9 In India the teacher is perceived as a type of intermediary, a channel for the transmission of sacred knowledge between the gods and the pupils. In Japan it is possible to perform ritual music only by identifying with the god or through the virtual personification of God (Keister 2005, 46).

${ }^{10}$ At Vilnius University operate the Centre of Oriental Studies, the Confucius Institute, at Vytautas Magnus University (in Kaunas) - the Centre for Asian Studies; the subject "Musical Non-European Cultures" is taught at the Lithuanian Academy of Music and Theatre, and so forth.
}

Anyhow, an increasing interest of younger generations in Eastern culture and religion has a profound impact on the present-day conception of sutartines as well on their various interpretations, both singing them in a capella and combining their singing with other musical styles or instruments (Indian bansuri flute, tabla), and the like. For example Lyla, a unique project of the famous Lithuanian folk music singer Veronika Povilioniene and the performers of Indian classical music merges archaic Lithuanian folk songs and instrumental improvisations performed in the Hindustani tradition. In their music these two apparently different cultures enrich each other and converge, revealing their distant, but common, Indo-European origins. In 2004 Lyla released the widely acclaimed album Bitinélio raga (Bee Raga) ${ }^{11}$.

The group Atalyja ("The rain is coming") positioned itself as a Lithuanian folk-rock music band presents an exciting combination of folk, rock and funk, with some features of Indian classical music (the group was awarded as the ethnoband of the year at the alternative music awards "A.LT"-2008). Well-known Lithuanian musicians and ethnomusicolo-gists are among the members of the band. Some songs are coloured with oriental shades of North Indian instruments: the bansuri as well as tabla ${ }^{12}$.

\section{Concluding remarks}

Some present-day examples of the sutartines revival should be regarded as part of the mass culture, in which the reverence towards the East occurs as an attempt of people with Western identity to compensate, at least on a mental level, for the values and meanings that they lack in their immediate environment.

On the other hand, experimental crossover mixtures of the sutartines with any kind of Eastern musics can be understood as an acceptable method for young people to 'open up to the world,' to shape their own 'Lithuania-as-part-of-the-world.' This may offer a very fruitful perspective for the spread of the sutartines tradition and promotion of the national culture at large. To align our argument with the thoughts of philosopher and art researcher Antanas Andrijauskas, the national culture that eschews "the longing for the world's culture" has no future. The greater the ability of culture to naturally integrate the values of other cultures, the more profound impulses it receives for its growth (Andrijauskas, 1991, 253). Such peaceful dialogue of cultures may nonetheless

\footnotetext{
11 The sutartine "Ka bice", performed by Lyla and Veronika Povilioniene, https://www.pakartot.lt/album/ bitinelioraga (accessed Januar 27, 2017).

${ }^{12}$ The sutartine "Gervelè" ["The Crane"], performed by folk rock band Atalyja (from CD "Močia" (2004)), https://www.youtube.com/watch?v=YBnBeF-1Y90; accessed Januar 25, 2017).
} 
lead to the problem of cultural transfer: that is, how to transfer meanings of 'foreign' cultures into one's native culture without damaging its authenticity. But one thing remains certain: it is through the natural integration of other cultures' and civilizations' values that we achieve a better understanding and appreciation of the specificity, spiritual riches and possibilities for self-realization that lie within our own culture.

One of the latest examples of such dialogue of cultures is the musical performance "A Merriadge of Sutartines and Flamenco" (Flamenko ir sutartiniu jungtuvess $^{13}$. Sutartines and flamenco ${ }^{14}$ are enormously contrasting forms of expression of ethnic traditions and to a rational mind they do not fit, however, quite the opposite is true. Due to their unique differences they actually complement each other by exposing the hidden links, the beauty and richness of both cultures. [Fig. 5]

"Mugam and sutartines: dialogue" (Mugamas ir sutartines: dialogai) another original project bringing together different cultures (symbolically representing the West and East). It was the first and the only, unique project in Lithuania connecting Azerbaijani and Lithuanian folk music ${ }^{15}$ [Fig. 6]. This project unites not just two ethnic cultures and also completely different music styles: polyphony and monody, rock, fusion, free jazz, electro music ${ }^{16}$.

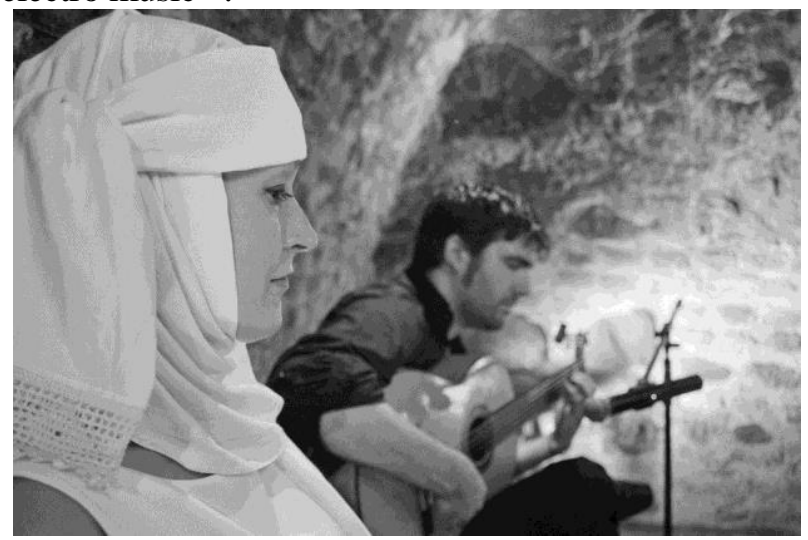

${ }^{13}$ It's a theatrical musical story about a meeting between Flamenco and Sutartines, love, nuptials, honeymoon and all that was born out of it. It is a performance of conti?uous movement and flow of inevitable interconnection. ("Sutartinès meets Flamenco", http://flamenkofilmufestivalis.lt/performance/; accessed Januar 18, 2017).

${ }^{14}$ As is known flamenco is at the heart of Southern Spain's Andalusian culture, connecting the singing, dancing and the guitar. The natural blend of Romani, Christian, Arabic, Sephardic, African, South American, and the local Spanish indigenous cultures played a role in developing the art of Flamenco.

15 A promotional video recording of performance "Mugam and sutartines: dialogue", https://www.youtube.com/ watch?v=Mqc4IloUxNc; accessed Januar 18, 2017)

16 "Mugam ir sutartinès: dialogai" [Mugam and sutartines: dialoguel http://www.terminal.menufabrikas.lt/en/mugam -ir-sutartin\%C4\%97s-dialogai; accessed Januar 18, 2017)
Figure 5. Singer and author of the performance "A Merriadge of Sutartines and Flamenco" Brigita Bublyte with flamenco musician Javier Gomez (guitar, Spain) (Dmitrijus Matvejevas, photographer, 2014)

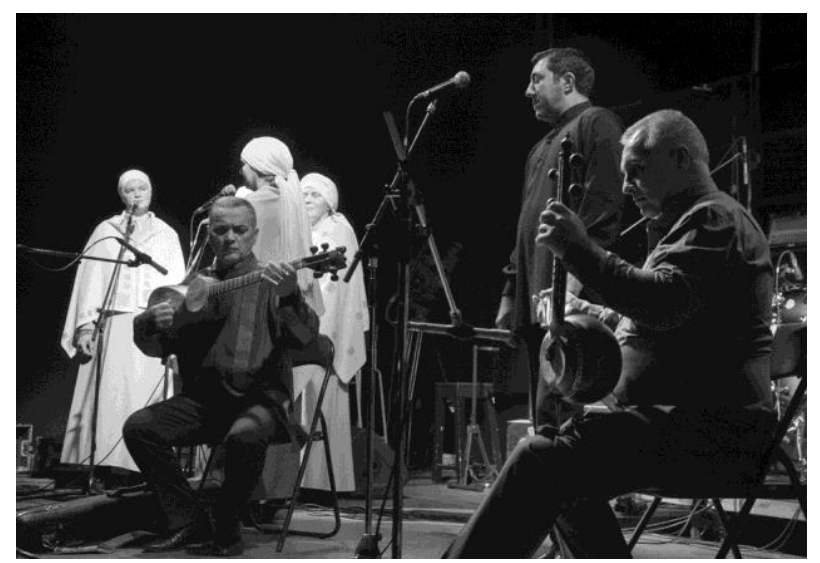

Figure 6. Mugam musicians (Elshan Mansurov, Malik Mansurov and Ehtyram Huseynov) with sutartines' singers group Trys Keturiose during the concert in Vilnius (Vytautas Daraškevičius, photographer, 2015)

I hope that the understanding Eastern culture helps singers and musicians envisage modern possibilities of "western" meditation in sutartinès. However, another possibility, which cannot be excluded, is that the spirit of the East rather than the West lies in the very nature of sutartines.

The spirituality of contemporary sutartines performance practice manifests itself as an inner experience of holiness, as the harmonization of self, and as a communal feeling - as musical and universal coherence, a developing relationship with the listener, joy emanating from the result, as enlightenment. 


\section{References}

Andrijauskas, Antanas. (1991). "Orientalizmas Vakarų filosofijoje ir dailèje 'Orientalism in Western philosophy and art'.” In Orientas 1, 253-282. Vilnius: Vaga.

Baldi, Philip, and Dini, Pietro U. (Ed.) (2004). Studies in Baltic and Indo-European Linguistics. In Honor of William R. Schmalstieg. Amstredam/Philadelphia: John Benjamins Publishing.Beinorius, Audrius. (2011). "Dvasingumas ir sąmoningumas: apie budizmo meditacinių praktikų vaidmenį šiuolaikinëje Vakarų psichoterapijoje 'Spirituality and consciousness: On the role of Buddhism spiritual practices in the modern Western psychotherapy'." In Inveniens quaero: ieškoti, rasti, nenurimti. Vilnius: Vilnius Pedagogical University publishing house. 199-213.

Deschênes, Bruno. (2005). "The Interest of Westerners in Non-Western Music." The World of Music: The Music of "Others" in the Western World 47/3: 5-29.

Dovydaitis, Jurgis. (Ed.) (1987). Pasakos su dainuojamaisiais intarpais 'Fairy tales with singing insertions'. Comp. and ed. by Jurgis Dovydaitis. Vilnius: Vaga.

Geist, Edwin. (1940). Antikes und Modernes im litauischen Volkslied. Kaunas: Pribačis Publisher.

Genzelis, Bronislovas. (2005). "Pirmieji lietuvių žvilgsniai ị Rytų kultūras 'The first Lithuanian looks into Eastern cultures'.” In Rytai-Vakarai: komparatyvistines studijos 'East - West: Comparatyvistic studies' IV. Kultūrogija 12, 384-396. Andrijauskas, Antanas, comp. Vilnius: Culture, Philosophy and Arts Research Institute.

Guénon, René. (2002). “Rytų ir Vakarų priešprieša 'East-West confrontation'.” In La crise du monde moderne [a fragment]. Paris: Gallimard. Translated from the French by Linas Rybelis. Metai 2005/10.

Jasinskaitė-Jankauskienè, Inga. (2001). Pagoniškasis avangardizmas. Teoriniai Broniaus Kutavičiaus muzikos aspektai 'Pagan Avant-Garde. Theoretical Aspects of Music by Bronius Kutavičius'. Vilnius: Gervelè.

Jung, Carl Gustav. (1970). Psychology and Religion: West and East, Volume 11, Collected Works of C. G. Jung. Adler, Gerhard and Hull, R. F.C., ed. Princeton, N.J.: Princeton University Press.

Keister, Jay. (2005). "Seeking Authentic Experience: Spirituality in Western Appropriation of Asian Music." The World of Music 47/3:37-53.

Landsbergytė, Jūrate. (2011). "Orientas lietuvių muzikoje. Dvasinių erdvių ilgesys 'The orient in Lituanian Music Longing for Spiritual Spaces'.” In Rytai-Vakarai: komparatyvistinès studijos 'East-West: Coparative Studies' XI, 529-538. Andrijauskas, Antanas, ed. Vilnius: Lietuvos kultūros tyrimų institutas 'Lithuanian Culture Reaserch Institute

Markevičienė, Žaneta. (2002). "Lietuvių, hindi ir sanskrito kalbų leksinès bendrybės 'Common Lexical Items in Lithuanian, Hindi and Sanscrit'." Kalbotyra 'Linguistics' LI/1: 99-114.

Neimantas Romualdas. (2002). “Šiuolaikinès Lietuvos kultūros plètros pagrindinè kryptis: keistis, kad išliktum savimi 'The main direction of modern Lithuanian culture development: Change to survive themselves'.” Mokslo Lietuva 22/268: 20.

Niemi, Aukusti Roberti and Sabaliauskas, Adolfas (ed.). (1912). Lietuviu dainos ir giesmés šiaurrytineje Lietuvoje 'Lithuanian Songs and Hymns in Northeastern Lithuania'. Helsinki-Riga: Suomių literatūros draugijos spaustuvè 'Society of Finnish Literature Printers'.

Račiūnaitè-Vyčinienè, Daiva. (2002). Lithuanian Polyphonic Songs Sutartinès. Vilnius: Vaga.

Račiūnaitė-Vyčinienè, Daiva. (2005). "Articulation of Sutartinès: Viewpoints of Insider and Outsider." In Traditional Music and Research in the Baltic Area. New Approaches in Ethnomusicology. Astrauskas, Rimantas, ed., 231-243. Vilnius: Lithuanian Academy of Music and Theatre, Department of Ethnomusicology.

Račiūnaitė-Vyčinienė, Daiva. (2010). "Two Ways the Sutartines Have Spread in Modern Culture: the Sacred and Profane." In The Fourth International Symposium on Traditional Polyphony. Proceedings 15-19 September 2008, 237-250. Tbilisi, Georgia. Tsurtsumia, Rusudan, and Jordania, Joseph, ed. Tbilisi: Tbilisi State Conservatoire.

Račiūnaitè-Vyčinienè, Daiva (2012a). "Specific features in performing Lithuanian multipart songs sutartinès: singing as birdsong." In Multipart music: a specific mode of musical thinking, expressive behavior and sound. Papers from the First Meeting of the ICTM Study Group on Multipart Music, September 15-20, 2010, Cagliari, Sardinia. Macchiarella, Ignazio, ed. Nota, Udine. 215-236.

Račiūnaitė-Vyčinienè, Daiva (2012b). "The revival of Lithuanian polyphonic sutartinès songs in the late 20th and early 21 st century." Res Musica 4:97-115.

Šalkauskis, Stasys. 1991. Pedagoginiai raštai 'Pedagogical writings'. Karčiauskienè, M., and Paulauskas, R., comp. Kaunas: Šviesa, 1991.

Schmalstieg, William R. (1982). “The Lithuanian Language - Past and Present.” Lituanus 28/1:4-100.

Slaviūnas, Zenonas, ed. 1958-1959. Sutartinès: Daugiabalsès Lietuvių Liaudies Dainos 'Sutartinès: Polyphonic Lithuanian Folk Songs'. Edition 1-3. Vilnius: Valstybinè grožinès literatūros leidykla.

Tamošaitis, Regimantas. (2012). Orientas lietuvių literatūroje 'Orient in Lithuanian literature'. Educational book for philology students. Vilnius: Vilniu University.

Yusfin, Abram [Юсфин, Абрам]. 1968. “Политональность в литовской народной музыке 'Polytonality in the Lithuanian folk music'.” In Studia Musicologica. Vol. X, nr. 1-4. Budapest: Akademiai Kiado. 323-337.

Yusfin, Abram [Юсфин, Абрам]. (1986). “О целостьности композиции в остинатных формах народной музыки (тезисы к проблеме) 'On the wholeness of composition in ostinatic forms of folk music (theses to the problem)]Bottom of Form.' In Проблемы традиционной инструментальной музыки народов СССР 'Problems of traditional instrumental music of the peoples of the USSR'. Ленинград: ЛГИТМиК. 157-170.

Vèlius, Norbertas. (1977). Mitinès lietuviu sakmiu bütybès 'Mythological beings of Lithuanian legends'. Vilnius: Mintis. 


\section{Sound and video examples:}

Ex. 1. Du dobilèli trys ratilèli. Sung by sutartinès' singers group Trys Keturiose (from CD “Sutartinès" 1, nr. 18, Vilnius: Boma Record, 2003), https://www.pakartot.lt/album/sutartines-2-cd/du-dobileliu-trys-ratileliu2 (accessed Januar 18, 2017)

Ex. 2. Trys keturiose linelius sejjam. A fragment from audiovisual project "Lino Laikas" [Linen Times], performed by Trys Keturiose in Kaunas (filmed by Leonas Glinskis, 2009)

Ex. 3. Sadūto tūto. Sung by sutartinès' singers group Trys Keturiose in sutartinès' festival "Sesé Sodų Sodina” [Sis Plants the Orchard] in Ramučiai, Kaunas district (filmed by Virginijus Kašinskas, 2014).

\section{Кафедра етномузикології Литовської академї музики і театру вул. Вільняус 6-2, LT-01110 Вільнюс, Литва тел.+370 524974 87, e-mail: daiva.vyciniene@lmta.lt}

\section{Литовські поліфонічні пісні сутартінес сьогодні: співвідношення Західної та Східної культур}

Дихотомія «Схід-Захід»є філософською концепцією давнього походження. Не зважаючи на те, що Схід і Захід можна розуміти як культурні опозити, необхідно говорити про їх спільність у певних точках дотику. Спираючись на багатолітню практику співу і наукові дослідження, автор доводить, що музика сутартінес розуміється не як суміш різних вокальних партій, а як звуковий пульсуючий простір. В цьому сенсі сутартінес близькі до мінімалістичних - музичних та візуальних творів, які характеризуються багаторазовим повторенням елементів, їх строгістю і точністю. Під час виконання сутартінес, як і у традиційній східній музиці, характерною рисою є те, що за допомогою контрольованих емоцій, виконавець входить у певний стан і перебуває у ньому певний час (з власного співацького досвіду авторки). Говорячи про сутартінес, автор звертається до теми литовських стосунків зі Сходом, які є не так географічні, як психологічні. Відомо, що Захід у цілому схильний до пошуку насамперед виявів духовності на Сході. Тому зв'язки можуть розглядатися як одна з можливостей такого пошуку. Автор торкається питання, чи не є сучасне прагнення молоді співати сутартінес результатом пошуку духовності у східній культурі, тобто чи закладений в самій природі сутартінес "дух Сходу", а не "дух Заходу"? Проекти сучасної музики, які об'єднують західну і східну культури, допомагають зрозуміти оригінальні риси сутартінес і можливості «західної» медитації.

Ключові слова: сутартінес, литовський мінімалізм, духовність, Захід-Схід, діалог культур

Дайва Рачюнайте-Вичинене

Кафедра этномузыкологии Литовской академии музыки и театра ул. Вильняус 6-2, LT-01110 Вильнюс, Литва тел.+370 524974 87, e-mail: daiva.vyciniene@lmta.lt

\section{Литовские полифонические песни сутартинес сегодня: соотношение Западной и Восточной культур}

Дихотомия «Восток-Запад» является философской концепцией давнего происхождения. Несмотря на то, что Восток и Запад можно понимать как культурные оппозиты, необходимо говорить об их общности в определенных точках соприкосновения. Опираясь на многолетнюю практику пения и научные исследования, автор доказывает, что музыка сутартинес понимается не как смесь различных вокальных партий, а как звучащее пульсирующее пространство. В этом смысле сутартинес близки минималистичным - музыкальным и визуальным произведениям, которые характеризуются многократным повторением элементов, их строгостью и точностью. Во время исполнения сутартинес, как и традиционной восточной музыки, характерной чертой является то, что с помощью контролируемых эмоций исполнитель входит в определенное состояние и пребывает в нем определенное время (из личного исполнительного опыта автора). Говоря о сутартинес, автор обращается к теме литовских отношений с Востоком, которые не столько географические, сколько психологические. Известно, что Запад в целом склонен к поиску прежде всего проявлений духовности на Востоке. Поэтому связи могут рассматриваться как одна из возможностей такого поиска. Автор задается вопросом, не является ли современное стремление молодежи петь сутартинес результатом поиска духовности в восточной культуре, не заложен ли в самой природе сутартинес «дух Востока», а не «дух Запада»? Проекты современной музыки, которые объединяют западную и восточную культуры, помогают понять оригинальные черты сутартинес и возможности «западной» медитации.

Ключевые слова: сутартинес, литовский минимализм, духовность, Запад-Восток, диалог культур

Стаття надійшла до редакиії 24.05.2019 p. 